\title{
Varian Produksi, Manajemen Keuangan dan Pemasaran Usaha Mikro Kerupuk Kerang Madurasa di Kabupaten Bangkalan
}

\author{
Buaddin Hasan ${ }^{1 *}$, Atya Rizkiana ${ }^{2}$ \\ 1.2 STKIP PGRI Bangkalan
}

\section{A R T I C L E I N F O}

\section{Article history:}

Received 15 March 2018 Received in revised form 10 May 2018

Accepted 30 June2018

Available online 23 ugust 2018

\section{Kata Kunci:}

Varian Produksi,

Manajemen Keuangan,

Pemasaran, Kerupuk

kerang, Usaha Mikro

Keywords:

Production Variant,

Financial Management,

Marketing, Shellfish

Crackers, Micro Business

\begin{abstract}
A B S T R A K
Program Program Kemitraan Masyarakat (PKM) kelompok usaha Kerupuk Kerang Madurasa Produk Madura Citarasa Nusantara di kelurahan Pejagan Kabupaten Bangkalan merupakan usaha peningkatan kesejahteraan masyarakat di sekitar pesisir Kabupaten Bangkalan dengan cara mengolah kerang menjadi kerupuk kerang. Proses pelaksanaannya bekerjasama dengan 2 mitra yang sama-sama bergerak dalam usaha home industri pembuatan kerupuk kerang. Metode yang digunakan dalam pelaksanaan program PKM ini adalah metode pelatihan, pendampingan dan evaluasi. Metode pelatihan merupakan upaya mendidik dan melatih mitra agar mampu mengembangkan usahanya. Hasil dari pelaksanaan program kemitraan masyarakat ini, berupa varian bentuk produk kerupuk kerang yaitu bulat pipih, kotak pipih dan stik. Adanya variasi, packaging yang menarik dan sistem pemasaran yang tekonsep berdampak pada peningkatan hasil usaha yaitu $50 \%$ dari produksi awal.
\end{abstract}

\section{A B S T R A C T}

Community Partnership Program (PKM) Madurasa Shellfish cracker business group Madura Citarasa Nusantara products in Pejagan village Bangkalan Regency is an effort to improve the welfare of the people around the coastal area of Bangkalan by processing shellfish into shellfish crackers. The implementation process is in collaboration with 2 partners who are both engaged in the home industry of making shellfish crackers. The method used in implementing this PKM program is a method of training, mentoring and evaluation. The training method is an effort to educate and train partners to be able to develop their business. The results of the implementation of the community partnership program are in the form of variants of shellfish crackers, namely flat round, flat boxes and sticks. There are variations, attractive packaging and marketing systems that have the concept of increasing the yield of the business which is $50 \%$ of the initial production.

Copyright (C) Universitas Pendidikan Ganesha. All rights reserved.

\footnotetext{
${ }^{*}$ Corresponding author.

E-mail addresses: buaddinhasan@stkippgri-bkl.ac.id (Buaddin Hasan), atyarizkiana@stkippgri-bkl.ac.id (Atya Rizkiana
} 


\section{Pendahuluan}

Pada dasanya Usaha Mikro harus senantiasa mendapatkan perhatian dari berbagai kalangan, baik oleh pemerintah maupun pemilik modal guna keberlangsungan usahanya. Usaha Mikro adalah bentuk demokrasi ekonomi yang mampu memperpendek ketimpangan antara yang bermodal dengan yang sedikit modal. Usaha yang bercirikan kerakyatan tersebut lebih mampu bertahan terhadap fluktuasi ekonomi internasional, dan juga peluang untuk memberdayakan masyarakat yang berada di sekitar lebih besar dibandingkan dengan industri yang menengah ke atas.

Pengembangan kerjasama kemitraan strategis antara publik, privat dan masyarakat pada dasarnya erat kaitannya dengan domain administrasi publik (Dewi,2013). Menurut Kusumadewi (2013) kemitraan merupakan suatu strategi bisnis yang dilakukan oleh dua pihak atau lebih dalam jangka waktu tertentu untuk meraih keuntungan bersama dengan prinsip saling membutuhkan dan saling membesarkan. Kemitraan adalah suatu bentuk kerja sama atas dasar kesepakatan dan rasa saling membutuhkan dalam rangka meningkatkan kapasitas dan kapabilitas di suatu bidang usaha tertentu atau tujuan tertentu sehingga memperoleh hasil yang lebih baik (Fahmi, 2013). Kemitraan adalah adaptasi dari partnership yang merupakan bentuk persekutuan antara 2 pihak atau lebih untuk menjalin suatu kerjasama yang berdasarkan kepada sebuah kesepakatan guna meningkatkan kapasitas untuk mencapai tujuan guna memperoleh capaian hasil yang lebih baik (Indriawati,2015). Menurut Alkadrie (2012) program kemitraan merupakan program yang bertujuan untuk meningkatkan kemampuan Usaha Kecil dan Menengah sebagai mitra binaan agar menjadi tangguh dan mandirisehingga dapat meningkatkan taraf hidup masyarakat. Program kemitran masyarkat ini merupakan bentuk pengabdian kepada masyarkat di Kabupaten Bangkalan. Menurut Aini (2016) program kemitraan merupakan program peminjaman dana bergulir kepada masyarakat yang terdampak. Melihat adanya sumber daya alam yang melimpah di Pesisir Kabupaten Bangkalan yaitu kerang laut, maka perlu untuk dikembangkan berupa pengabdian kepada Usaha Mikro di Kabupaten Bangkalan. Bentuk pengabdian ini meliputi pengembangan manajemen usaha kerupuk kerang. Manajemen usaha sangat berpengaruh terhadap keberlangsungan suatu usaha. Hal ini senada dengan penelitiannya Evawati (2010) Besarnya kerang yang dihasilkan yang mempunyai kandungan kalsium dan protein yang cukup tinggi, fortifikasi kalsium pada produk krupuk untuk peningkatan nilai gizi dan peluang usaha pasca panen hasil perikanan. Berdasarkan hal tersebut adanya sumber daya alam berupa kerang di pesisir Kabupaten Bangkalan layak untuk dikembangakan dalam usaha mikro kerupuk kerang.

Dalam program program kemitraan masyarakat Kelompok Usaha Kerupuk Kerang Madurasa (Produk Madura Citarasa Nuasantara) di Kelurahan Pejagan Kabupaten Bangkalan dengan 2 mitra usaha yang bergerak dalam produksi kerupuk kerang. Banyaknya jumlah kerang yang dihasilkan yang mempunyai kandungan kalsium dan protein yang cukup tinggi, fortifikasi kalsium pada produk krupuk dapat meningkatkan nilai gizi dan peluang usaha pasca panen (Evawati, 2010)

Pemilik usaha kerupuk kerang adalah Ibu Aminah yang beralamat di Jl. KH. Abadul Muin Rt.02 Rw.07 Kelurahan Pejagan Kecamatan Bangkalan Kabupaten. Usaha ini didirikan sejak tahun 1986 dan bergerak pada bidang pembuatan kerupuk kerang.

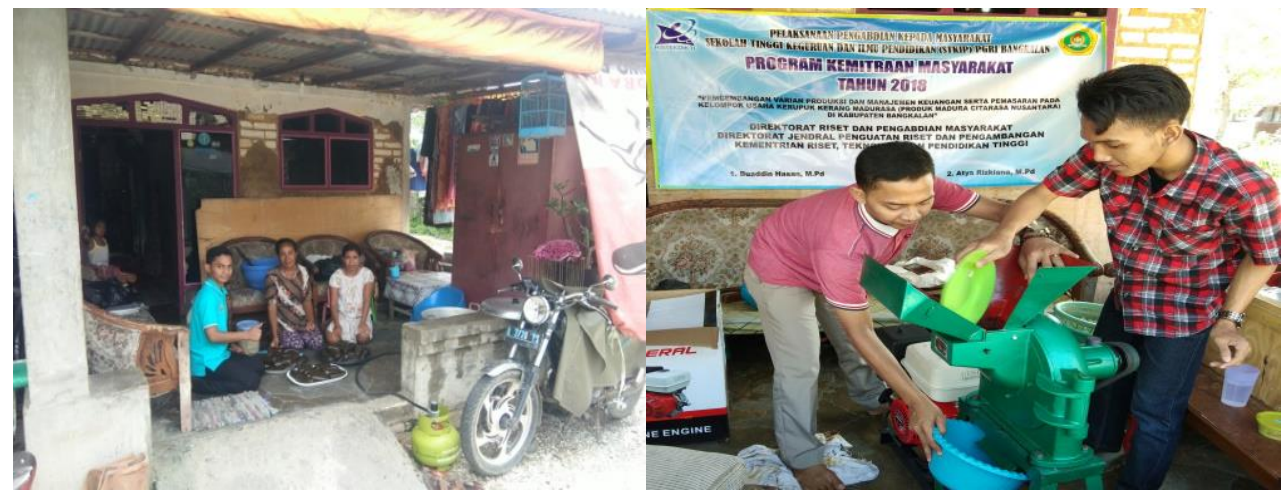

Gambar 1.1 Proses Pengabdian

Usaha kerupuk kerang ibu Aminah belum terdaftar di BP POM dan belum mempunyai ijin usaha, hal ini karena kurangnya modal dan pengetahuan ibu Aminah dalam mengurus administrasi usaha. Usaha ibu Aminah kurang mampu bersaing dengan produk kerupuk lainnya. Ibu aminah hanya mengandalkan 
pesanan dari tetangga ataupun langganan yang sudah mengenal kerupuk kerang ibu Aminah. Meskipun harganya sangat terjangkau pesanan kerupuk kerang ibu Aminah hanya ramai pada bulan-bulan tertentu, misalnya; pada saat bulan puasa, idul adha dan bulan maulid nabi.

Bahan baku utama kerupuk kerang usaha ibu aminah adalah kerang, tepung tapioka dan bumbu-bumbu, namun perbedaan dengan kerupuk kerang yang sudah ada, ibu Aminah menambahkan tripang pada adonan kerupuk sehingga citarasanya menjadi lebih gurih. Kerupuk kerang tersebut dijual mentah masih mentah. Kemasan 1 kg kerupuk kerang mentah ibu Aminah dijual dengan harga Rp 50.000.sedangkan untuk kemasan 50 gram dijual dengan harga Rp. 26.000.-

Sejak memulai usahnya ibu Aminah sampai sekarang hanya memproduksi kerupuk kerang tiga hari sekali. Dua tahun terakhir ini usaha kerupuk kerang ibu aminah sedikit mengalami penurunan produksi. Pada awalnya ibu aminah mampu memproduksi kerupuk kerang setiap harinya mencapai $20 \mathrm{~kg}$ kerupuk kerang mentah, namun pada akhir-akhir ini hanya memproduksi 10-15 kg per 2-3 hari. Hal ini terjadi karena kurangnya manajemen pemasaran sehingga kalah bersaing dengan produk makan baru yang lebih tertata secara manajemen usaha. (Sumber: hasil wawancara dengan Ibu Aminah pemilik Home industri Kerupuk Kerang).

Berdasarkan hasil wawancara pengusul dengan mitra (Usaha Rumahan Kerupuk Kerang Ibu Aminah) mengatakan bahwa produk kerupuk kerangnya bisa dikembangkan seperti halnya produk kerupuk kerupuk "Udang dan Rengginang Lorjuk" yang sudah sangat terkenal di Kabupaten Bangkalan sebagai oleh-oleh khas daerah. Untuk mencapi ke arah tersebut, menurut ibu Aminah (pemilik usaha kerupuk kerang), "perlu adanya keterampilan dalam pengembangan varian bentuk yang lebih menarik, sehingga lebih manarik minat para pembeli. Selain itu juga perlu beberapa mesin yang dapat memudahkan dalam proses produksi, diantaranya mesin pengaduk adonan, mesin iris, dan alat pres packing. Dan juga perlu disain kemasan yang menarik untuk menarik minat para konsumen. Ibu Aminah optimis jika peningkatan kualitas (seperti halnya diatas) ditingkatkan, apalagi ada peningkatan perbaikan dalam kemasan dan proses pemasaran yang lebih bersaing, maka nilai jualnya juga akan semakin meningkat.
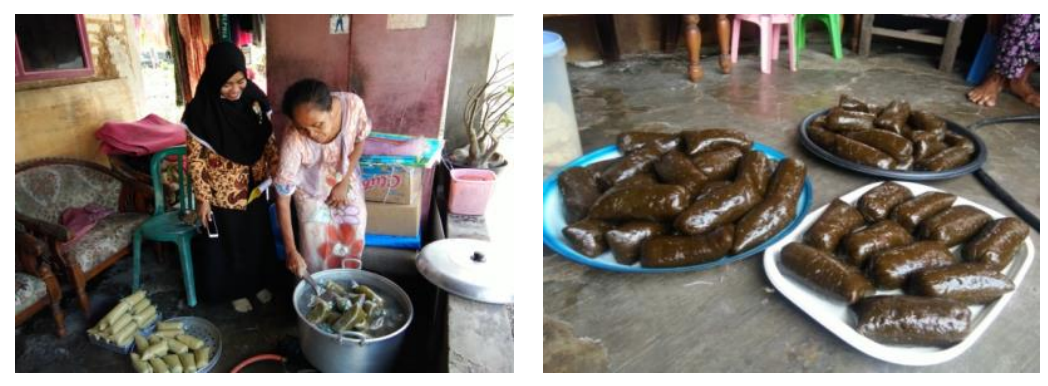

Gambar 2 Proses Pengolahan Kerupuk Kerang Ibu Aminah

Dari sisi manajemen, Usaha kerupuk kerang ibu Aminah merupakan usaha keluarga. Oleh karenanya Usaha ini belum menggunakan prinsip-prinsip manajemen yang baik. Misalnya belum ada pembukuan tentang keuangan usaha, masih belum memisahkan antara keuangan usaha dan keuangan pribadi. Ibu Aminah Pemilik Usaha Kerupuk Kerang mengharapkan bahwa usaha yang dimiliki pembukuan yang jelas dan terperinci tentang keuangan usaha mulai dari pengadaan bahan baku, biaya proses produksi (tenaga kerja, gas dan lain-lain) dan biaya pemasaran (ongkos pengiriman barang). Selain itu Ibu Aminah mengharapkan untuk dapat membuat laporan keuangan usaha, karena suatu usaha yang memiliki laporan keuangan usaha lebih diprioritas mendapatkan bantuan dari perusahaan yang memberikan bantuan CSR (Corperate Social Responsibility), disamping itu seringkali sebagai syarat untuk mendapatkan kredit dari lembaga pemberi pinjaman.

Dari sisi manajemen yang lain adalah pada manajemen pemasaran, menurut Ibu Aminah: "Hasil produksi selama ini dijual di rumah sendiri, dititipkan di Toko sekitar dan produksi berdasarkan pesanan". Ibu Aminah mengharapkan pengembangan usaha yang dimiliki, dimana produksinya bisa dipasarakan di Toko oleh-oleh makanan khas Bangkalan, tempat-tempat wisata dan juga melalui media online (Seperti FB, WA, Instagram, dan media lainnya).

Sedangkan mitra yang kedua adalah usaha rumahan kerupuk kerang milik ibu Lailis Devi Maulindin yang beralamat di Jaln Anggrek, Kemayoran Kabupaten Bangkalan. usaha ini didirikan sejak 10 tahun yang lalu dan masih mampu memproduksi kerupuk kerang sampai saat ini. Sama halnya dengan usaha ibu Aminah, usaha ibu Lailis belum mempunyai ijin usaha. Usaha kerupuk kerang ibu Lailis masih bersifat home insdustri yang merupakan usaha keluarga. Dalam memproduksi kerupuk kerang ibu Lailis dibantu oleh 2 orang anaknya dan 1 orang karyawan yang merupakan tetangganya sendiri. 
Hasil wawancara denga ibu Lailis bahwa usaha kerupuk kerang miliknya setiap hari mampu memproduksi kerupuk kerang $15 \mathrm{~kg} /$ hari. Bahan baku utama kerupuk kerang ibu Lailis adalah kerang Geltek (kerang hijau) yang di dapat dari nelayan disekitar rumah ibu Lailis. Stiap 1 kg kerang geltek (kerang hijau) dicampur dengan $2 \mathrm{~kg}$ tepung dan beberapa bumbu. Setiap $1 \mathrm{~kg}$ kerupuk kerang mentah ibu Lailis dijual dengan harga Rp. 48.000. selain dijual mentah ibu Lailis juga menjual kerupuk keragnya yang sudah diolah (sudah digoreng) dengan kemasan 100 gram seharga Rp. 7.500.-. propses pemasarannya dijual dirumah dan berdasrkan pesanan dan juga ada langganan toko-toko kecil yang membantu menjualnya. Kendala utama yang dihadapi ibu Lailis dalam pengembangan usahanya adalah kepemilikan modal yang sedikit, kemdian kurangnya pengetahuan dalam proses manajemen usahanya, baik dari segi pemasaran maupun tata kelola usahanya.

Melihat perkembangan Kabupaten Bangkalan yang terus berupaya mengembangkan dunia pariwisata dan UMKM guna peningkatan kesejahteram masyarakat serta ketersediaan bahan baku utama kerang yang melimpah di daerah pesisir Kabupaten Bangkalan, usaha rumahan kerupuk kerang milik ibu Aminah dan Ibu Lailis sangat berpotensi untuk dikembangkan. Baik dari aspek produksi maupun aspek manajemen.

Proses produksi kerupuk kerang yang tidak terlalu sulit dan murah memungkinkan mitra untuk mengembangkan usahanya. Hal ini didukukung adanya: a) Ketersedianya bahan utama yaitu kerang geltek (kerang hijau), karena kedua mitra membeli kerang dari nelayan yang berada disekitar rumahnya, b) Banyak ibu rumah tangga yang tidak bekerja sehingga bisa diberdayakan untuk menjadi tenaga kerja usaha rumahn produksi kerupuku kerang, c) Biaya produksi kerupuk kerang yang murah, karena kedua mitra membeli bahan baku utama "kerang" dari nelayan di sekitar rumahnya di kelurahan Pejagan.

Untuk menjamin ketercapaian pengembangan usaha kedua mitra. Pengusul bersama mitra menyusun manajemen usaha dengan melihat beberapa aspek, diantaranya; a) Aspek kualitas, dalam produksi produk mitra tetap selalu konsisten menjaga kualitas dan rasa agar tetap laku di pasaran, b) Aspek packing, proses pengemasan produk didesain semenarik mungkin agar dapat menarik minat pembeli, c) Aspek pemasaran, lokasi kabupaten Bangkalan yang strategis dengan adanya jembatan suramadu menjadikan proses pemasaran kerupuk kerang yang sangat menjanjikan, proses pemasaran produk melalui: (1) Mendirikan stand rumahan, (2) distribusi ke toko tempat wisata di Bangkalan, (3) pemasaran melalui media sosial ( Google, FB, BBm, WA, Instagram). dan (4) Mendirikan stand di sekitar akses jembatan Suramadu, d) Aspek harga, harga penjualan kerupuk akan disesuaikan dengan harga dipasaran sehingga mampu bersaing.

Dalam mendukung keberlangsungan usaha juga didukung dengan sumber daya yang memadai.

a. Sumber daya manusia, produksi krupuk kerang tidak memerlukan keahlian khusus, sehingga pemberdayaan ibu rumah tangga di kelurahan pejagan sangat memungkinkan untuk direkrut menjadi tenaga kerja, disamping itu pembuatan kerupuk kerang tidak telalu sulit sehingga pengusul bekerjasama dengan mitra usaha cukup diberikan pelatihan dan pendampingan dalam produksi, packing, proses manajemen dan pemasaran. Hal ini dapat dilakukan selama program PKM ini berlangsung.

b. Sumber daya alam, kelurahan Pejagan sebagaian besar masyarakatnya hidup dipesisir dan mata pencahariannya adalah nelayan, sehingga pasokan sumber daya alam (kerang) sangat mendukung keberlangsungan usaha krupuk kerang Ibu Aminah dan Ibu Lailis. Data hasil wawancara dengan kedua mitra, menyatakan bahawa setiap hari para nelayan mencari kerang dengan pendapatan sekitar $2 \mathrm{~kg} /$ hari kerang, sedangkang jumlah masyarakat nelayan sekitar 25 orang. Dengan demikian setiap hari kelurahan Pejagan bisa menyediakan pasokan kerang sekitar 50 kg kerang. Dengan masyarakat pencari kerang pasokan bahan baku utama usaha kerupuk kerang bisa terpenuhi. Hal ini juga akan menjamin keberlangsungan produksi Kerupuk Kerang ibu Aminah dan Ibu Lailis

Hasil diskusi bersama kedua mitra (ibu Aminah dan Ibu Lailis), menyimpulkan bahwa permasalahan dasar yang dihadapi dalam produksi usaha kerupuk kerang diantaranya; a) Kesulitan dalam pengembangan usaha (Kurangnya pengetahuan dan keterampilan mitra dalam mebuat ragam bentuk kerupuk kerang, selam ini bentuk kerupuk kerang produksi kedua mitra berbentuk "tidak beraturan", sehingga kurang menarik minat konsumen), b) Kurangnya pengetahuan dalam bidang pemasaran produk. Mitra kurang mengerti bagaimana cara memasarkan hasil produknya dengan memanfaatkan media. Selama ini mitra hanya memasarkan berdasarkan pesanan dan menitipkan di tokotoko kecil. Kuranganya pengetahuan dalam bidang manajemen usaha. Mitra tidak mengerti bagaimana menyusun laporan keuangan usaha. 


\section{Metode}

Pelaksanaan program pengabdian kemitraan masyarakat ini dilakukan dengan beberapa metode, yaitu; Pertama, metode mediasi dilakukan dengan berdiskusi bersama mitra membahas persiapan yang diperlukan untuk memulai pelaksanaan program PKM. Pengusul menyusun jadwal pelatihan, mendisain dan membuat alat yang diperlukan dalam rangka menyelesaiakn permasalahan mitra. Kedua, metode pendidikan masyarakat berupa in-house training, metode ini dilakukan untuk mmeberikan pelatihan kepada mitra dalam pengembangan variasi bentuk kerupuk kerang madurasa. Adapun bentuk yang diinginkan adalah bulat pipih, stik dan kotak pipih. Pada tahap pelaksanaan tim pengusul juga melakukan evaluasi hasil variasi bentuk kerupuk kerang. Kemudian melakukan pendampingan sampai mitra benarbenar mengerti membuat variasi bentuk "kerupuk kerang madurasa". Ketiga, Metode Disfusi Iptek dilakukan untuk mempermudah mitra dalam produksi, yaitu dengan memanfaatkan teknologi dalam proses produksi. Menggunakan mesin giling listrik, mesin iris dan mesin packaging.

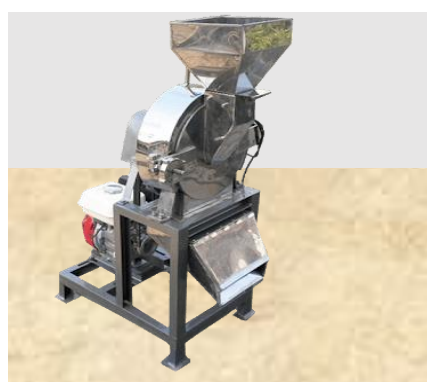

Mesin Giling Adonan

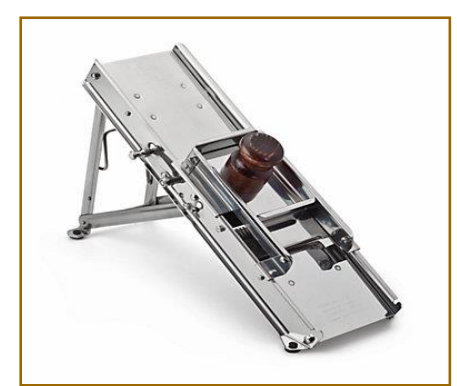

Mesin Iris Kerupuk

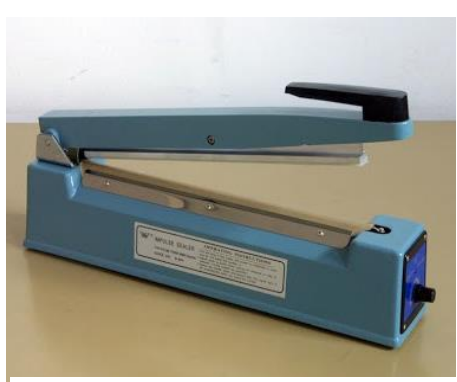

Mesin Press Packaging

Gambar 4. Disfusi Iptek Dalam Produksi

Metode Subtitusi Ipteks memberikan gambaran cara memasarkan produk dan melakukan pendampingan sampai mitra benar-benar mampu memasarkan produk dengan baik. Usaha yang dilakukan untuk memasarkan kerupuk kerang diantaranya melalui media social (FB, WA, BBm, Blogger). dan juga bermitra dengan toko-toko yang menjual produk oleh-oleh khas Kabupaten Bangkalan. Keempat, metode advokasi memberikan pelatihan bagaimana cara mengelola usaha dengan baik. Pelatihan yang dilakukan meliputi; manajeman pembukuan sederhana mengenai keuangan usaha. Mulai dari biaya bahan, biaya produksi sampai pada hasil penjualan. Dan juga pelatihan manajemen pembukuan dalam penyusunan laporang keuangan usaha.

Indikotor keberhasilan program pengabdian ini antara lain: 1) Adanya peningkatan kualitas dan hasil produksi kerupuk kerang antara 20\% s.d 50\% dari produksi awal, 2) Adanya varian bentuk kerupuk kerang yang beraneka, 3) Adanya manajeman usaha berupa pembukuan laporan keuangan usaha

\section{Hasil dan pembahasan}

Pelaksanaan porgram kemitraan masyarakat ini menghasilkan peningkatan dalam usaha kerupuk kerang madurasa. Adapun hasil dari program PKM ini antara lain; a) Dengan adanya pengadaan 1 (satu) unit mesin pengaduk adonan (mixer) dan 1 (satu) unit alat pemotong/pengiris, 1 unit mesin packaging menjadikan usaha kerupuk kerang ibu Lailis dan ibu Aminah mengalami peningkatan produksi kerupuk mencapi 50\%. Yakni dari semula produksi kerupuk perhari sebanyak $20 \mathrm{~kg} / \mathrm{hari}$, sekarang mampu memproduksi rata-rata mencapai $30 \mathrm{~kg} / \mathrm{hari}$, b) Terjadi peningakatan kualitas produksi kerupuk. Dimana perubahan/penambahan kualitas produk dilihat dari varian bentuk, nama dan packaging.

\section{1) Bentuk Produk}

Bentuk semula kerupuk kerang ibu aminah dan ibu Lailis tidak beraturan, sehingga minat konsumen sedikit, setelah adanya proses pendampingan pengetahuan pengembangan varian bentuk, kerupuk kerang kerang ibu Aminah dan ibu Lailis mempunyai 3 bentuk yang bervariasi, yaitu : bulat pipih, kotak pipih dan stik. 
Tabel 1. Varian Bentuk Kerupuk Kerang Madurasa

\begin{tabular}{lll}
\hline No & Kondisi Aktual & Hasil Yang dicapai \\
\hline 1 & Bentuk tidak beraturan & Bentuk Bulat Pipih \\
& & Kotak Pipih \\
& & Bentuk Stik \\
\hline
\end{tabular}

2) Icon Produk

Selain perubahan bentuk kerupuk kerang ibu Aminah dan Ibu Lailis, ada pula perubahan nama yang menjadi brand penjual untuk mempermudah konsumen mengenalnya. Nama produk tersebut adalah "Kerupuk Kerang Madura Ibu Aminah" dan "Kerupuk Kerang Madurasa Ibu Lailis". Nama produk tersebut menjadi icon dari kerupuk kerang khas Kabupaten Bangkalan dengan jargon "Madurasa" yang mempunyai arti "Produk Madura Citarasa Nusantara". Dengan demikian konsumen dapat mengenal produk dengan mudah dan diminati.

3) Packaging

Dari segi packaging, semula kerupuk kerang kedua mitra dikemas secara sederhana. Namun setelah dilakukan pendampingan maka ada kreasi baru dalam pengemasan agar lebih menarik daya beli konsumen, adapun gambar kemasan produksi kerupuk kerang madurasa seperti pada gambar 5 .
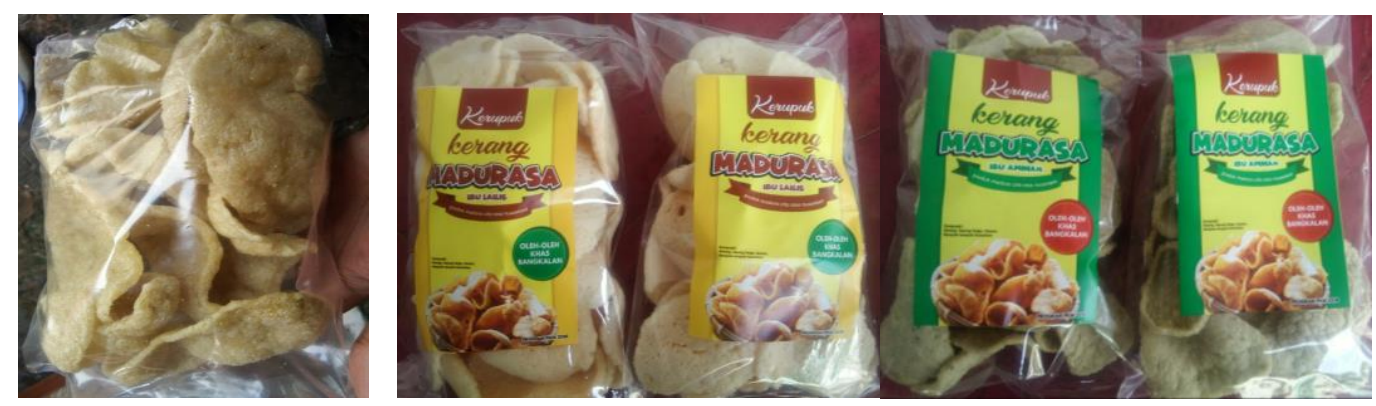

Gambar 5. Packaging Kemasan Kerupuk Kerang Madurasa Sebelum dan Sesudah Program PKM

Dalam aspek manajeman, Program PKIM usaha kerupuk kerang madurasa memberıkan dampak perubahan dalam aspek manajemen usaha, program yang dilakukan meliputi:

a. Memberikan pelatihan pembukuan sederhana.

Dalam manajemen usaha, program PKM memberikan pelatihan pembukuan sederhana kepada mitra, hal ini dilakukan agar mitra mampu mengontrol dan mengelola keuangan dengan baik.

Tabel 2. Manajemen Keuangan Usaha

\begin{tabular}{|c|c|c|}
\hline No & Kondisi Aktual & Hasil Yang dicapai \\
\hline 1 & $\begin{array}{l}\text { Belum ada pembukuan tentang } \\
\text { keuangan usaha. }\end{array}$ & $\begin{array}{l}\text { Ada pembukuan yang jelas dan terinci } \\
\text { tentang keuangan usaha, yang meliputi: } \\
\text { I. Pengadaan bahan baku } \\
\text { Biaya proses produksi (tenaga kerja, } \\
\text { listrik, gas dan lain-lain) } \\
\therefore \text { Penerimaan penjualan } \\
\text { l. Laporan keuangan sederhana }\end{array}$ \\
\hline 2 & $\begin{array}{l}\text { Belum memisah-kan keuangan usaha } \\
\text { dan pribadi }\end{array}$ & $\begin{array}{l}\text { ada pemisahan antara keuangan priabdi } \\
\text { dengan keuangan usaha }\end{array}$ \\
\hline
\end{tabular}

Dengan adanya pembukuan sederhana usaha kerupuk kerang madurasa dapat mengetahui laporan keuangan dari hasil usaha. Di samping itu ada tata administrasi keuangan yang jelas sehingga tidak sehingga jelas antara keuangan pribadi dan keuangan uasaha. 


\section{b. Manajemen Pemasaran}

Setelah dilakukan pendampingan pemasaran melalui berbagai pameran, jaringan pemasaran Usaha Kerupuk Kerang Madurasa milik Mitra PKM menjadi lebih luas, proses pemasaran dilakukan dengan media distribusi dan online.

Tabel 3. Manajemen Pemasaran

\begin{tabular}{cll}
\hline No & \multicolumn{1}{c}{ Kondisi Aktual } & \multicolumn{1}{c}{ Hasil Yang dicapai } \\
\hline 1 & Dijual dirumahan & Dijual di toko oleh khas Bangkalan \\
& & Tempat wisata \\
& Toko rekanan \\
2 & Menunggu pesanan & Melalui media sosial diantaranya \\
& BBm \\
& Facebook \\
& WA \\
& IG \\
\hline
\end{tabular}

Dengan pelaksanaan PKM baik yang dilakukan pada Usaha Kerupuk Kerang Ibu Aminah dan Usaha Kerpuk Kerang Ibu Lailis, dimana masing-masing telah diberikan 1 unit mesin pengaduk adonan (mixer),1 unit alat pemotong/pengiris, 1 unit mesin packaging telah terjadi peningkatan produksi kerupuk 50\%, yakni dari semula produksi kerupuk perhari sebanyak $20 \mathrm{~kg} /$ hari, sekarang menjadi rata-rata $30 \mathrm{~kg} / \mathrm{hari}$. Dari segi rasa produk setelah dilaksanakan pelatihan PKM ini, bentuk produk menjadi 3 (tida) varian yaitu bulat pipih, kotak pipih dan stik. Dari sisi manajemen keuangan, setelah dilaksanakannya Program PKM ini, mitra mulai melakukan pembukuan terinci tentang keuangan usaha mulai dari mulai pengadaan bahan baku dan biaya proses produksi (tenaga kerja, listrik, gas dan lain-lain). Disamping itu memiliki kemampuan membuat laporan keuangan sederhana. Dari sisi manajemen pemasaran, setelah dilakukan pendampingan pemasaran dengan mengenalkan media marketing via online dan distribusi rekanan, produksi kerupuk kerang madurasa dapat diorder secara online, dapat dibeli di toko khas oleh-oleh Kabupaten Bangkalan, dapat dibeli di toko tempat-tempat wisata, dan toko yang menjadi rekanan pemasaran produk. Hal ini dilakukan dalam rangka peningkatan kuliatas pemasaran dan layanan kemapada konsumen sehingga dapat meningkatkan pendapatan.

Program kemitraan masyarakat ini telah berhasil meningkatkan produksi kerupuk kerang madurasa, keberhasilan tersebut berupa; adanya varian bentuk kerupuk (bulat, pipih dan stik) serta kuliatas kerupuk yang semakin baik dari segi rasa mapun packaging, disamping itu program ini telah berhasil membuat jargon kerupuk kerang Maduras (produk madura citarasa nusantara) sebagai icon kerupuk, sehingga berdampak pada minat konsumen. Menurut Ghanimata, F., \& Kamal, M. (2012) kualitas produk dan lokasi terbukti secara positif dan signifikan dapat mempengaruhi minat konsumen. Hal tersebut juga senada dengan pendapat Hariadi, D. (2015) yang menyatakan bahawa packaging (kemasan) serta icon produk dapat mempengaruhi konsumen dalam keputusan pembelian suatu barang. Program ini juga telah membantu memberikan pelatihan kepada mitra tentang proses pemasaran produk, sehingga diakhir program mitra telah mampu memasarkan produk via online, dan kerjasama dengan toko rekanan dengan mengedepankan layanan kepada konsumen. Menurut Aryani, D., \& Rosinta, F. (2011) bahwa terdapat pengaruh yang kuat dan positif antara kualitas layanan terhadap loyalitas pelanggan.

\section{Simpulan dan saran}

Simpulan dari kegiatan pengabdian ini antara lain: 1) Dengan adanya pengadaan 1 unit mesin pengaduk adonan (mixer),1 unit alat pemotong/pengiris, 1 unit mesin packaging telah terjadi peningkatan produksi kerupuk 50\%, yakni dari semula produksi kerupuk perhari sebanyak $20 \mathrm{~kg} / \mathrm{hari}$, sekarang menjadi rata-rata $30 \mathrm{~kg} / \mathrm{hari}$, 2) Terjadi peningakatan kualitas produksi kerupuk kerang madurasa. Dimana peruba-han/penambahan kualitas produk dilihat dari varian bentuk, 3) Dalam hal bentuk produk, setelah dilaksanakannya Program Iptek bagi Masyarakat (IbM) ini, bentuk produk menjadi 3 (tiga) varian bentuk, yaitu (bulat pipih, kotak pipih, stik), dan 4) Setelah dilaksanakannya Program Kemitraan Masyarakat (PKM) ini, mitra mulai melakukan pembukuan terinci tentang keuangan usaha mulai dari mulai pengadaan bahan baku dan biaya proses produksi (tenaga kerja, listrik, gas dan lain-lain). Serta memiliki kemampuan membuat laporan keuangan sederhana. Setelah dilakukan pendampingan pemasaran melalui media online, pemasaran produk semakin berkembang yang berdampak pada peningkatan hasil usaha. 


\section{Daftar Rujukan}

Aini, Nurul dan Dasim Budimansyah. 2016. Kemandirian Masyarakat Bangka Dalam Pengembangan Tanggung Jawab Sosialperusahaan(Studi Kasus pada PT Timah Pangkalpinang Kepulauan Bangka Belitung). Jurnal Moral Kemasyarakata, VOL.1, NO.2.

Alkadrie, Syarif Agussaid. 2012. Analisis Dampak Program Kemitraan Terhadap Pemasaran Produk Usaha Kecil Dan Menengah Pada PT Jasa Raharja (Persero) Cabang Kalimantan Barat. Jurnal Bisnis dan Keuangan, Vol.2, No.1.

Aryani, D., \& Rosinta, F. (2011). Pengaruh kualitas layanan terhadap kepuasan pelanggan dalam membentuk loyalitas pelanggan. BISNIS \& BIROKRASI: Jurnal Ilmu Administrasi dan Organisasi, $17(2)$.

Dewi,Kartika Tribuana dkk. 2013. Kemitraan Peternak Sapi Perah Dengan Kud "Batu" Dalam Meningkatkan Ekonomi Masyarakat Peternak Sapi Perah. Jurnal Administrasi Publik, Vol. 1, No.4.

Evawati, Diana. 2010. Pemanfaatan Kerang Fortifikasi Kalsium Pada Krupuk Aneka Rasa Untuk Peningkatan Kandungan Gizi Dan Tingkat Penerimaan Konsumen. Jurnal Akp. No. 2.

Fahmy,Amri Yulian. 2013. Pelaksanaan Program Kemitraan Pemerintah Dan Masyarakat Dalam Penataan Lingkungan Permukiman Berbasis Komunitas (Studi Pada Dinas Cipta Karya Tata Ruang dan Desa Sengguruh Kecamatan Kepanjen Kabupaten Malang). Jurnal Administrasi Publik. Vol.1, No.6.

Ghanimata, F., \& Kamal, M. (2012). Analisis pengaruh harga, kualitas produk, dan lokasi terhadap keputusan pembelian (studi pada pembeli produk bandeng juwana elrina semarang) (Doctoral dissertation, Fakultas Ekonomika dan Bisnis).

Hariadi, D. (2015). Pengaruh produk, harga, promosi dan distribusi Terhadap keputusan pembelian konsumen Pada produk projector microvision. Jurnal Ilmu \& Riset Manajemen, 1(8)

Indriawati,Ella Nur dkk. 2015. Implementasi Program Kemitraan Dan Bina Lingkungan Dalam Pembinaan Pengrajin Batik (Studi pada PT Semen Indonesia (Persero) Tbk Tuban dan Pengrajin Batik Tulis "Gedog" di Kecamatan Kerek Kabupaten Tuban). Jurnal Administrasi Publik, Vol.3, No.5.

Kusumadewi,Tutut Adi dkk. 2013. Kemitraan Bumn Dengan Umkm Sebagai Bentuk Corporate Social Responsbility (CSR) (Studi Kemitraan PT. TELKOM Kandatel Malang dengan UMKM Olahan Apel di Kota Batu). Jurnal Administrasi Publik, Vol.1, No.5.

Prasojo, Eko (2004) People and Society Empowerment: Perspertif Membangun Partisipasi Publik. Jurnal Ilmiah Administrasi Publik Vol. IV, No. 2. Hal. 12-18.

Subkhie,Hasan dkk. 2012. Analisis Kelayakan Usaha Peternakan Ayam Pedaging dengan Pola Kemitraan di Kecamatan Ciampea Kabupaten Bogor. Jurnal Manajemen Pengembangan Industri Kecil Menengah, Vol.7, No.1.

Sumartono,Eko. 2016. Analisis Produksi Tembakau Rajangan Tipe Muntilanan Dalam Pola Kemitraan Cv. Merabu - Pt. Djarum Kudus. Jurnal Agrisep, Vol. 15, No. 2.

Suryana,Tatang.2014. Pengaruh Lingkungan Eksternal, Internaldan Etika Bisnisterhadap Kemitraan Usaha serta Implikasinya pada Kinerja Usaha Kecil. Jurnal Ilmiah Manajemen Kontigensi, Vol.2, No.2. 